\title{
COMMENTARY
}

\section{Should fresh blood be recommended for intensive care patients?}

\author{
Bertrand Guidet ${ }^{* 1-3}$ \\ See related research by Karam et al., http://ccforum.com/content/14/2/R57
}

\begin{abstract}
Fresh blood has many potential advantages over older blood, but there is no evidence that these properties translate into clinical benefit for intensive care patients. The observational multicenter study by Karam and colleagues provides some evidence suggesting that blood stored for less than 14 days is better than older blood in terms of new organ failure and reduction in length of stay in pediatric intensive care units. Though in favor of using young blood, this study suffers from several limitations. As a consequence, it is ethical and certainly pertinent to conduct a randomized clinical trial in order to test the hypothesis that fresh blood might reduce mortality. The rationale is strong and the potential benefit of fresh blood is substantial.
\end{abstract}

As reported in the previous issue of Critical Care, a prospective observational study conducted by Karam and colleagues [1] in 30 North American centers linked length of storage of red blood cell (RBC) units and outcome of critically ill children. This study is worth commenting upon since the literature documents conflicting results. The use of 'fresh blood' has several potential advantages over that of older blood. Young blood allows better 24-hour, post-infusion, in vivo recovery $[2,3]$. The RBC lysis releases free hemoglobin that binds nitric oxide (NO), inducing vasoconstriction [2].

Old blood is associated with several alterations either in the supernatants - a decrease of sodium and an increase of potassium [4], decreases of $\mathrm{pH}$ and arterial partial pressure of oxygen $\left(\mathrm{PaO}_{2}\right)$, increases of lactate and arterial partial pressure of carbon dioxide $\left(\mathrm{PaCO}_{2}\right)$ [2]

*Correspondence: bertrand.guidet@sat.aphp.fr

${ }^{3}$ Assistance Publique - Hôpitaux de Paris, Hôpital Saint-Antoine, Service de Réanimation Médicale, 184 rue du Faubourg Saint Antoine, 75012 Paris, France Full list of author information is available at the end of the article and procoagulant state [5], and an increased risk of thrombosis [6] - or related to cellular modifications such as a decrease of 2,3-DPG (2,3-diphosphoglycerate) [2] content, leading to an increase of hemoglobin oxygen affinity and a decrease of RBC deformability [2]. All of these alterations in stored RBCs lead to a reduction of $\mathrm{O}_{2}$ delivery. As a matter of fact, the oxygen uptake was improved after transfusion of fresh blood but was unchanged with older blood (28 days) in the study of Fitzgerald and colleagues [7] and tissue oxygenation was altered in trauma patients transfused with old blood [8].

Given the potential beneficial effects of fresh blood and also the logistical and financial impact of its recommendation, we need strong clinical scientific evidence in order to push hard to obtain fresh blood from the blood banks. The study by Karam and colleagues [1] is the first prospective multicenter study of its kind $(\mathrm{n}=296$ pediatric patients, younger than 18 years) to document that blood stored more than 14 days has detrimental effects on organ dysfunction (adjusted odds ratio 1.87, 95\% confidence interval 1.04 to $3.27 ; P=0.03$ ). This result was explained mainly by renal failure and was not associated with a reduction in mortality. It is worth noting that intensive care unit (ICU) length of stay was reduced (by 3.7 days). Accordingly, the cost-benefit ratio of fresh blood is probably very favorable.

\section{Limitations of the study Methodology}

This was an observational study, so we cannot be sure that patient groups were perfectly balanced. A matchedcohort study could have better addressed the question. Worse clinical outcome is associated with the number of transfusions independently of the longest length of storage and some patients received several blood transfusions that were not consistently stored for less than 14 days. The lack of consistency in the allocated group introduces a bias, but since the oldest blood is considered for defining the storage time, this inconsistency does not bias the results in favor of fresh blood. Of note, data on the length of storage were available for only $66 \%$ of the patients. 


\section{Quality of the blood}

Fresh blood was defined as RBC concentrates stored for a period shorter than the median length of storage, resulting in a cutoff value of 14 days. RBCs infused in North America are older than in Europe either in pediatric ICUs (14 days [9], 16 days [10]) or in adults, with a length of storage reaching 33 days in US military hospitals [11]. Leukoreduction is common practice in most Western countries but was performed in only $86 \%$ of the transfusions in this study.

Given the design of the study, it is not possible to state that there is a cause-and-effect relationship between older RBCs and outcome in critically ill patients. However, these encouraging results justify the large randomized clinical trial of adult patients which is already under way in Canada.

Abbreviations

ICU, intensive care unit; RBC, red blood cell.

\section{Competing interests}

The author declares that he has no competing interests.

\section{Author details}

'Inserm, Unité de Recherche en Épidémiologie Systèmes d'Information et Modélisation (U707), 184 rue du Faubourg Saint Antoine, 75012 Paris, France. 2UPMC Univ Paris 06, 184 rue du Faubourg Saint Antoine, 75012 Paris, France. ${ }^{3}$ Assistance Publique - Hôpitaux de Paris, Hôpital Saint-Antoine, Service de Réanimation Médicale, 184 rue du Faubourg Saint Antoine, 75012 Paris, France.

Published: 20 May 2010

\section{References}

1. Karam O, Tucci M, Bateman ST, Ducruet T, Spinella PC, Randolph AG, Lacroix J: Association between length of storage of red blood cell units and outcome of critically ill children: a prospective observational study. Crit Care 2010, 14:R57.
2. Bennett-Guerrero E, Veldman TH, Doctor A, Telen MJ, Ortel TL, Reid TS, Mulherin MA, Zhu H, Buck RD, Califf RM, McMahon TJ: Evolution of adverse changes in stored RBCs. Proc Natl Acad Sci U S A 2007, 104:17063-17068.

3. Luten M, Roerdinkholder-Stoelwinder B, Schaap NP, de Grip WJ, Bos HJ, Bosman GJ: Survival of red blood cells after transfusion: a comparison between red cells concentrates of different storage periods. Transfusion 2008, 48:1478-1485.

4. Karam O, Tucci M, Toledano BJ, Robitaille N, Cousineau J, Thibault L, Lacroix J, Le Deist F: Length of storage and in vitro immunomodulation induced by prestorage leukoreduced red blood cells. Transfusion 2009, 49:2326-2334.

5. Sweeney J, Kouttab N, Kurtis J: Stored red blood cell supernatant facilitates thrombin generation. Transfusion 2009, Apr 29. [Epub ahead of print].

6. Spinella PC, Carroll CL, Staff I, Gross R, Mc Quay J, Keibel L, Wade CE, Holcomb $J B$ : Duration of red blood cell storage is associated with increased incidence of deep vein thrombosis and in-hospital mortality in patients with traumatic injuries. Crit Care 2009, 13:R151.

7. Fitzgerald RD, Martin CM, Dietz GE, Doig GS, Potter RF, Sibbald WJ: Transfusing red blood cells stored in citrate phosphate dextrose adenine- 1 for 28 days fails to improve tissue oxygenation in rats. Crit Care Med 1997, 25:726-732.

8. Kiraly LN Kiraly LN, Underwood S, Differding JA, Schreiber MA: Transfusion of aged packed red blood cells results in decreased tissue oxygenation in critically injured trauma patients. J Trauma 2009, 67:29-32.

9. Bateman ST, Lacroix J, Boven K, Forbes P, Barton R, Thomas NJ, Jacobs B, Markovitz B, Goldstein B, Hanson JH, Li HA, Randolph AG; Pediatric Acute Lung Injury and Sepsis Investigators Network: Anemia, blood loss, and blood transfusions in North American children in the intensive care unit. Am J Respir Crit Care Med 2008, 178:26-33.

10. Lacroix J, Hébert PC, Hutchison JS, Hume HA, Tucci M, Ducruet T, Gauvin F, Collet JP, Toledano BJ, Robillard P, Joffe A, Biarent D, Meert K, Peters MJ; TRIPICU Investigators; Canadian Critical Care Trials Group; Pediatric Acute Lung Injury and Sepsis Investigators Network: Transfusion strategies for patients in pediatric intensive care units. N Engl J Med 2007, 356:1609-1619.

11. Spinella PC, Perkins JG, Grathwohl KW, Repine T, Beekley AC, Sebesta J, Jenkins D, Azarow K, Holcomb JB; 31 st Combat Support Hospital Research Working Group: Risks associated with fresh whole blood and red blood cell transfusions in a combat support hospital. Crit Care Med 2007, 35:2576-2581.

doi:10.1186/cc9011

Cite this article as: Guidet B: Should fresh blood be recommended for intensive care patients? Critical Care 2010, 14:158. 